\title{
Financial dependence of the PIIGS countries
}

\author{
Piotr Siemiatkowski ${ }^{1}$, Ewa Jankowska ${ }^{2}$ \\ ${ }^{1}$ Dept. of Internal and International Security, Nicolaus Copernicus University, Torun, Poland \\ ${ }^{2}$ Dept. of Economics, WSB Schools of Banking, Torun, Poland
}

\section{Email address:}

piotrs@umk.pl(P. Siemiatkowski), ewa.jankowska@wsb.torun.pl(E. Jankowska)

\section{To cite this article:}

Piotr Siemiatkowski, Ewa Jankowska. Financial Dependence of the PIIGS Countries. Journal of World Economic Research. Vol. 2, No. 5, 2013, pp. 89-94. doi: 10.11648/j.jwer.20130205.12

\begin{abstract}
In the paper, the authors presented the problems connected with the financial dependence of the PIIGS countries (the contractual name for a group of European countries with the highest debt which stands for the first letters of the names of countries: Portugal, Italy, Ireland, Greece and Spain). In the first part the issues related to the concept of the financial dependence were discussed. Then International Investment Position (IIP) of the PIIGS countries was compared with other countries of the European Union. The main part of the paper is analysis of the indicators of the financial dependence the PIIGS countries. The analysis of the proposed set of indicators caused that the authors drew particular attention to the situation that took place in Ireland. Therefore, the case of Irish economy was discussed in the detail way. At the end of the paper conclusions about the financial dependence of PIIGS countries were presented.
\end{abstract}

Keywords: Financial Dependence, International Investment Position, PIIGS Countries, Gross External Debt

\section{Introduction}

The financial crisis, which had affected most of the countries in the world a few years ago (the USA and the EU countries in particular), showed a number of serious, yet rarely perceived economic problems. It was triggered to a great extent by the highest ever degree of globalization of the world economy. It turned out that the national economies are densely interconnected. The situation in the global market has become the main determinant of national economic balance. It should be noted, however, that problems resulting from the crisis have not affected all of the economies to the same extent. Some of the economies survived the crisis in a better condition than others. The reason for that is, inter alia, a dissimilar level of financial dependence of some individual economies on other ones.

Thanks to the opportunities created by the global market, the economic entities (companies, countries, international organisations) acting on foreign markets brought on financial dependence of individual regions and whole economies. More and more of the EU member countries became dependent on external financing.

On the basis of some previous researches carried out by the authors it has been assumed that this particular type of economic dependence is reflected in mandatory statistical reporting of the EU countries presented in a document entitled "International Investment Position" [1]. The paper prepared once a year by national central banks presents annual changes of net international investment position (NIIP), defined as a measure of capital flows between economies. The NIIP is therefore the most appropriate source of information about the extent to which a given country is dependent on external financing or to which it makes other countries dependent.

The issue of the high degree of financial dependence of a given economy significantly influences its basic macroeconomic parameters. Therefore one can assume that financial dependence of a country has a significant impact on its macroeconomic balance. The dependent economies involuntarily lose their complete control over macroeconomic processes.

\section{The Concept of the Financial Dependence}

The contemporary global economy is characterized by a significant dynamics of the international financial flows. The volume of cash that flows through the markets has long since exceeded the value of world exports of goods. Money, which was established to improve the exchange of goods, has become a commodity - the subject of many speculation and exchange. A multitude of financial instruments available on the market causes that many institutions and people try to 
use them for a fast enrichment, even at the cost of increased risk [2]. This in turn affects the stability of the market. The practice of recent years shows that the system of connected vessels, which has become the global economy; it is extremely sensitive to any turbulences.

The disappearance of borders, the removal of barriers in the trade and in the flow of factors of production, has resulted in rise to a number of transnational corporations, including financial corporations. The economic power of the transnational corporations is often much greater than the individual countries. Thus they can subordinate themselves other corporations, and even the whole economies. Some countries behave in this regard just like the transnational corporations.

The economic dependence is one of the key issues of the contemporary economic security of the country [3]. The economic dependence is defined as a state of relations between the countries, which restricts the freedom to use their own resources or reaping the benefits. It is based on attempts to influence the decisions of the state using economic instruments. This is a long process, which takes place in the base of bilateral economic relations that result in occurrence of disproportions in their mutual dependencies.

The financial dependence presented in this paper is the narrower concept. It deals with similar issues, but is limited to use only the tools of the financial origin. They affect the direction and the size of capital flows in the various forms. In economic terms, it boils down to locate in the territory of a foreign country appropriate quantity and quality of foreign investment [4]. At some point, it may prove that the country is financially dependent on the external entities. The scope of this dependency includes the capital market, the public debt, the private debt, and other areas, such as for example the labor market. When the size of the financial commitment of non-residents in the domestic economy becomes large enough that their sudden withdrawal would result in the destabilization, the situation becomes dangerous.

It should also be noted that the financial dependence facilitates the speculation of the global financial corporations. As practice shows, financial corporations use this opportunity to manipulate among others the level of the exchange rate, equity prices or valuation of government bonds [5].

\section{International Investment Position (IIP) of the PIIGS Countries against other Countries of the European Union}

The objects of the analysis undertaken in this study are so-called PIIGS countries. The presentation of the detailed situation regarding financial dependence will be preceded by the analysis of net international investment position of this group of countries against other members of the European Union. The ratio of international investment position (IIP) to gross domestic product (GDP) reflects the international financial situation of the economy. Although there are some exceptions to this rule (e.g. Italy), but clearly one can observe the relationship between the current financial situation in the country and the evolution of its international investment position. Admittedly the value of net international investment position (NIIP) of the country does not determine clearly the negative phenomena occurring in the economy, however, as the Greek example showed, it is highly probable.

In the worst situation in terms of the relation of NIIP to GDP are sequentially: Latvia, Portugal, Ireland, Hungary, Spain, Bulgaria and Greece "Fig. 1". It is significant that four of the seven above-mentioned countries belong to the group of PIIGS.

In the most worrying situation among the PIIGS countries is Greece. This country is in fact a bankrupt. Admittedly the ratio of net international investment position to GDP is not recently the worst, but it is no secret that the Greek economy works only with the help of other members of the European Union and the International Monetary Fund.

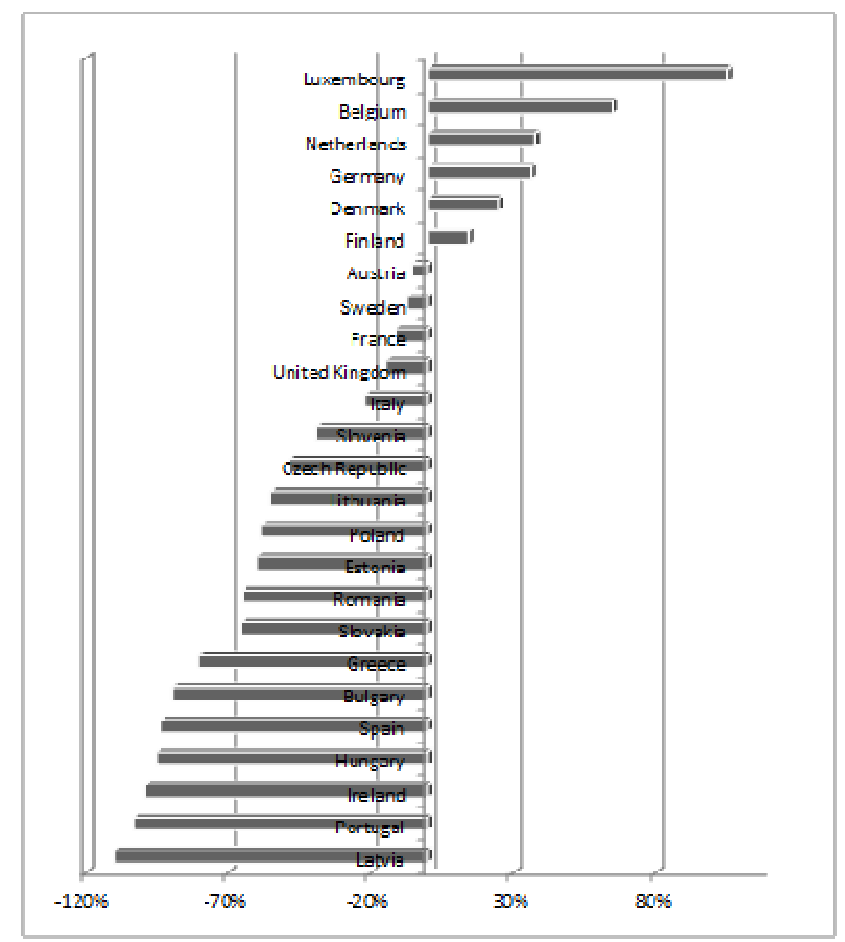

Figure 1. International investment position of the European Union countries in relation to Gross Domestic Product (in \%)

Particular attention is paid to a very bad international investment position of Spain. It takes negative values and its ratio to GDP approaching $100 \%$. This situation is worrying because Spain is one of the largest economies in the European Union (participation in the GDP of EU stands at nearly $9 \%$ ). At first mainly portfolio investment balance was responsible for the negative international investment position of this country. Today, however, this balance is reduced in favor of a gradual expanding of the balance of other investments. These processes do not show high 
dynamics. However, if the situation on international markets will be worse, this condition may quickly change. It should also be noted that the participation of Spain in the creation of GDP of the EU is much larger than Greece. Therefore, the deterioration of the situation in this country may have a much greater impact on the European Union than the last problems of the Greek economy.

Another two of the PIIGS countries, such as Ireland and Portugal, are in worse situation than Spain. In case of both these countries international investment position is negative and the ratio of IIP to GDP exceeds $100 \%$. The spread of the Greek problems on other EU countries may prove very dangerous. Due to a variety of financial relationships in the banking sector, the debt market and capital markets, this could have a domino effect.

In the case of the last of the PIIGS countries, i.e. Italy, the situation is different than the other four countries. Despite the fact that Italy is now one of the most indebted countries in the EU, the ratio of negative international investment position to GDP ratio is not high (approximately -25\%). This follows the fact that the gross domestic product of Italy is one of the highest not only in the EU but also in the world. Therefore, the ratio of even significantly negative international investment position to GDP is not as high as in the other PIIGS countries.

In the case of other countries of the European Union one should note that only six of them achieve a positive value of net international investment position. So these countries can be defined as the net lenders. Thus other countries to a greater or lesser extent become the net borrowers. In many as thirteen cases, the ratio of NIIP to GDP exceeds 50\%. This does not mean the financial troubles yet. But in comparison with the disastrous, in most cases, the public debt statistics, this is not a good omen for the future [6].

\section{The Proposals and Analysis of the Indicators of the Financial Dependence the PIIGS Countries}

The concept of the financial dependence of the economy is a term not often exposed in the literature. Thus there are not any universal measures which may reflect the scale of this phenomenon. Therefore, the authors of this study proposed three major indicators. They will enable to compare, at least to some extent, the financial dependence in the particular countries.

Table 1. Basic indicators of the financial dependence of the PIIGS countries in the 2002-2011

\begin{tabular}{ccccccccccccc}
\hline Country & Indicator & $\mathbf{2 0 0 2}$ & $\mathbf{2 0 0 3}$ & $\mathbf{2 0 0 4}$ & $\mathbf{2 0 0 5}$ & $\mathbf{2 0 0 6}$ & $\mathbf{2 0 0 7}$ & $\mathbf{2 0 0 8}$ & $\mathbf{2 0 0 9}$ & $\mathbf{2 0 1 0}$ & $\mathbf{2 0 1 1}$ \\
\hline \multirow{3}{*}{ Greece } & external liabilities/GDP & 1,0 & 1,1 & 1,2 & 1,4 & 1,6 & 1,8 & 1,7 & 2,0 & 2,0 & 1,9 \\
& FPI/GDP & 0,5 & 0,6 & 0,7 & 0,9 & 0,9 & 1,1 & 0,9 & 1,0 & 0,7 & 0,4 \\
& OFI/GDP & 0,4 & 0,4 & 0,4 & 0,4 & 0,5 & 0,6 & 0,7 & 0,8 & 1,1 & 1,4 \\
\hline \multirow{3}{*}{ Spain } & external liabilities/GDP & 1,3 & 1,4 & 1,5 & 1,7 & 1,9 & 2,1 & 2,0 & 2,2 & 2,2 & 2,3 \\
& FPI/GDP & 0,5 & 0,5 & 0,7 & 0,8 & 1,0 & 1,0 & 0,9 & 1,0 & 0,9 & 0,8 \\
& OFI/GDP & 0,5 & 0,5 & 0,5 & 0,6 & 0,5 & 0,6 & 0,7 & 0,7 & 0,7 & 0,8 \\
\multirow{4}{*}{ Ireland } & external liabilities/GDP & 7,3 & 7,9 & 8,8 & 10,6 & 11,4 & 12,2 & 13,4 & 15,9 & 17,7 & 17,4 \\
& FPI/GDP & 3,4 & 3,9 & 4,8 & 6,3 & 6,9 & 7,0 & 7,1 & 9,0 & 10,6 & 10,6 \\
& OFI/GDP & 2,5 & 2,8 & 3,0 & 3,4 & 3,8 & 4,4 & 5,6 & 5,8 & 5,8 & 5,6 \\
\hline \multirow{3}{*}{ Portugal } & external liabilities/GDP & 1,9 & 2,0 & 2,1 & 2,3 & 2,5 & 2,7 & 2,6 & 2,9 & 2,9 & 2,7 \\
& FPI/GDP & 0,6 & 0,7 & 0,8 & 0,9 & 0,9 & 1,0 & 1,1 & 1,3 & 1,1 & 0,9 \\
& OFI/GDP & 1,0 & 1,0 & 1,0 & 1,1 & 1,2 & 1,2 & 1,1 & 1,2 & 1,3 & 1,4 \\
\hline \multirow{3}{*}{ Italy } & external liabilities/GDP & 1,0 & 1,0 & 1,1 & 1,3 & 1,4 & 1,4 & 1,3 & 1,4 & 1,4 & 1,4 \\
& FPI/GDP & 0,6 & 0,6 & 0,7 & 0,8 & 0,8 & 0,8 & 0,7 & 0,8 & 0,8 & 0,7 \\
& OFI/GDP & 0,3 & 0,3 & 0,3 & 0,3 & 0,4 & 0,4 & 0,4 & 0,3 & 0,4 & 0,3 \\
\hline
\end{tabular}

+ FPI - foreign portfolio investments, OFI - other foreign investment, GDP - gross domestic product

The first and the most general of the proposed indicators is the ratio of external liabilities to gross domestic product. This ratio shows the relationship of the sum of total liabilities of traders (residents of the economy) in comparison to non-residents to the economic potential of the country measured by gross domestic product. Exceeding the value of the index above 1 means that the value of external liabilities of residents becomes greater than the sum of the value of final goods produced by the factors of production which are located in this country.

The rank of the individual components of the external liabilities in the financial dependence is diverse. In this case, foreign portfolio investment plays the most important role. The specificity of this type of investments can very easily 
lead to a reduction in value of the portfolio. This in turn may contribute to the destabilization of the economic situation of the country of investment. Due to the short-term and often speculative nature of the portfolio investment, the important indicator of the country's financial dependence seems to be the ratio of sum of liabilities to gross domestic product.

The example of Greece shows that in the case of restructuring of external debt, the sum of portfolio investments in external liabilities (especially the sum of government bonds) decreases rapidly. Simultaneously the sum of the remaining foreign investments increases. This item of liabilities includes among others external loans for the government and non-governmental sector. Therefore, as the third indicator of the country's financial dependence, the ratio of other foreign investment to gross domestic product was adopted.

Relation of external liabilities to GDP for the countries of PIIGS was about $140 \%$ in the case of Italy, $190 \%$ for Greece, $230 \%$ for Spain, $270 \%$ for Portugal, and even $1740 \%$ for Ireland [7]. The situation of the latter country deserves special attention, because in the period of interest, i.e. in the years 2002 - 2011, the ratio of external liabilities to GDP increased by almost 2.5 times.

The indicator of foreign portfolio investment to gross domestic product took various values among the PIIGS countries. In the case of Greece, there has been a decline in the value of this ratio from $50 \%$ in 2002 to $40 \%$ in 2011 . For the other countries listed in Table 1, this value increased during the analyzed period. The smallest increase was observed in the case of Italy (from $60 \%$ to $70 \%$ ), and the largest for Ireland - almost three-fold.

In the years 2002 - 2011 the ratio of other foreign investments to GDP increased to the greatest extent in the case of Greece (from $40 \%$ to $140 \%$ ) and Ireland (from $250 \%$ to $560 \%$ ). In the case of the other three countries the ratio of these two values stood in 2011 at $50 \%$ for Italy, $80 \%$ for Spain and $140 \%$ for Portugal. Its value has increased since 2002 from about $20 \%$ in Italy to $40 \%$ in Portugal.

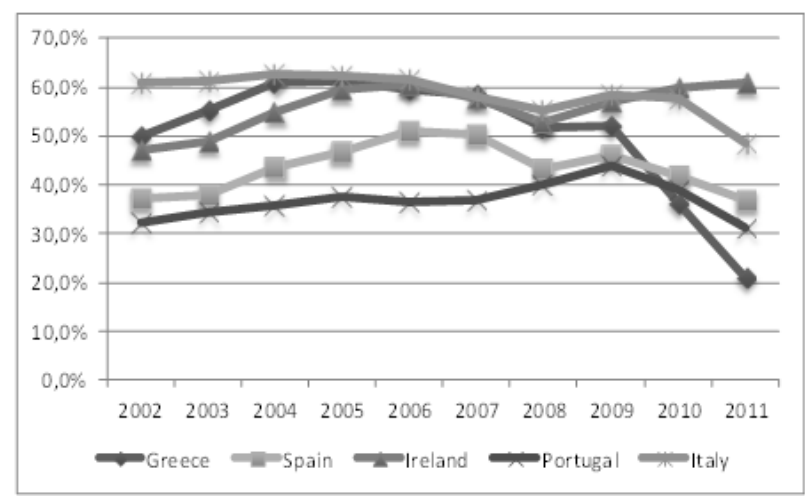

Figure 2. The ratio of portfolio investment to total external liabilities in the PIIGS countries in the years 2002-2011

As mentioned above, in extreme cases of insolvency of countries one can observe the process of substitution of portfolio investments by the so-called other investments in the external liabilities. This process is the result of redemption, through agreements with international financial institutions, the government bonds and replacing them with loans from these institutions. It is therefore necessary to trace the shares of both foreign portfolio investment and other foreign investment in total external liabilities of the PIIGS countries. Their occurrence reflects the financial problems of the country, and thus its dependence on external entities.

The ratio of foreign portfolio investment to liabilities for four PIIGS countries, namely Greece, Spain, Portugal and Italy, during the analyzed period was similar "Fig 2". Since 2009, this ratio decreased systematically, but the most spectacular falls noted for Greece. A little different situation was in the case of Ireland. Unlike the other PIIGS countries, the value of relationship between FPI and liabilities in the years 2009 - 2011 grew (from nearly $57 \%$ to about $60 \%$ ).

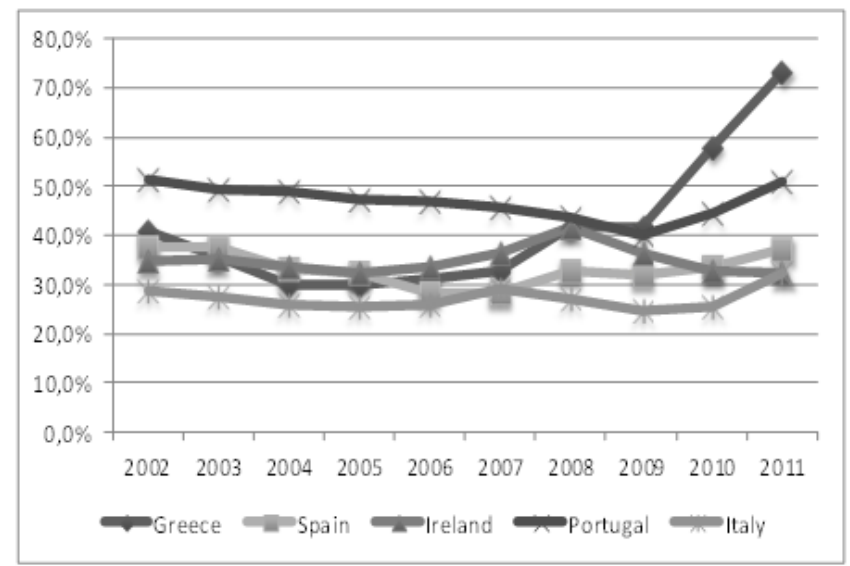

Figure 3. The ratio of other investments to total foreign liabilities in the PIIGS countries in the years 2002-2011

Figure 3 shows the relationship between other investments and liabilities. Of particular note are two countries: Greece and Portugal. In the first of those countries the value of this ratio decreased in the period $2002-2004$ (from nearly $41 \%$ to less than $30 \%$ ). Since 2006, it has started to grow, to achieve the highest growth in the years 2009 - 2011 (from nearly $42 \%$ in 2009 to over $73 \%$ in 2011 .). In the case of Portugal, the indicator showing the ratio of OI to liabilities slowly, but systematically decreased (from $51.6 \%$ to $40.1 \%$ ) in the years $2002-2009$. Since 2009 it began to significantly increase and stood at $44.5 \%$ in 2010 and almost $51 \%$ in 2011. In the case of the other three countries, changes of the value of analyzed index were not as significant.

The third component of external liabilities is direct investment. It is one of the basic forms of international capital flows in the contemporary world [8]. Due to its specificity, this type of investments is a kind of shock absorber for financially dependent countries. Long term planning horizon, pro-development nature, the impact on the labor market, on the infrastructure and flow of ideas, science and technology makes this type of investment highly desirable in the economy. The high share of direct investments in the foreign liabilities indicates a strong 
position of the country on the global market. This means that international corporations appreciate the stability of the economic situation and willing to invest a part of their capitals in a given place.

Foreign direct investments also contribute to the financial dependence of the economy, but it usually has a positive nature. Therefore, the "quality" of financial dependence, should be also described by the ratio of coverage of total foreign portfolio investment and other foreign investment by the resources of foreign direct investment in the economy. The high value of this ratio indicates that the financial dependence of the country is better "amortized" by the long-term direct investment. Even in the case of a sudden withdrawal of short-term investors, the economy will be less sensitive to the loss of balance of payments.

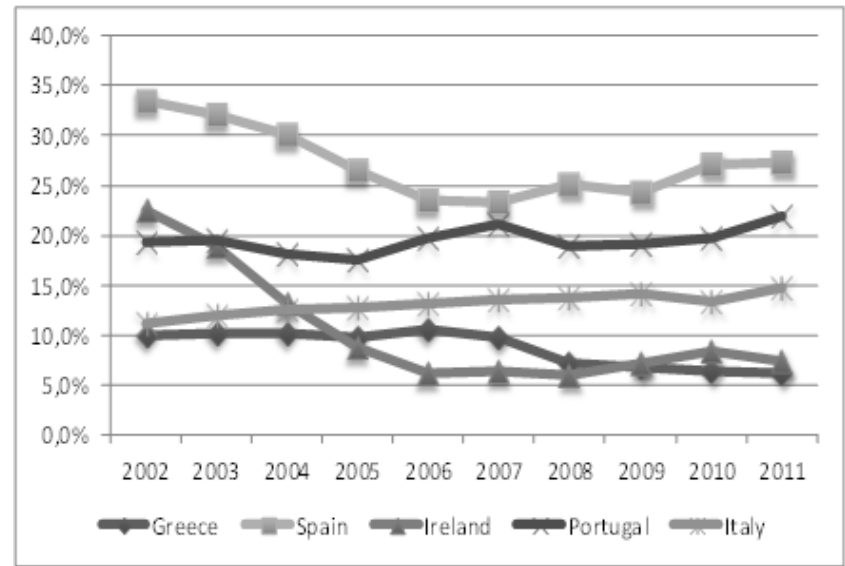

Figure 4. The ratio of other foreign direct investment to sum of foreign portfolio investment and other foreign investments in the PIIGS countries in the years 2002-2011

In the analyzed period, the index of foreign direct investment to total foreign portfolio investment and other investment has achieved different values in each of the five countries "Fig 4".

In Spain, its value strongly decreased in the years 2002 2006 (from $33.6 \%$ to $23.4 \%$ ). Since 2007, the value started to increase and in 2011 it reached $27.2 \%$. This was the highest rate among all the PIIGS countries. Therefore one can assume that Spain has the best structure of foreign liabilities in the analyzed group of countries.

In Italy, the above-mentioned index has increased significantly from $11.1 \%$ in 2002 to $14.7 \%$ in 2011 . For Portugal, the value of the relationship of FDI to FPI + OI decreases slightly in 2003-2005, then was increasing until 2007 and decreased again in 2008. Since 2009, this value has slowly increased (from about $19 \%$ to almost $22 \%$ ). In the case of Greece, this ratio remained unchanged in the years 2002 - 2007 and it was approximately 10\%. Since 2007, it began to steadily decrease and in 2011 it was equal about $6 \%$. The greatest changes of the value of the analyzed indicator were observed in the case of Ireland. In the years 2002 2006 its value dropped by over $16 \%$ (from $22.5 \%$ to $6.2 \%$ ). In the period 2006 - 2008 this ratio was roughly at the same level. In 2010 it increased to $8,3 \%$ and in 2011 it fell to $7.4 \%$.
This means that Ireland and Greece have the worst structure of foreign liabilities of the PIIGS countries.

\section{Ireland - the Case Study}

As follows from the above analysis, the case of Ireland is significantly different from the other PIIGS countries. It was not so publicized in the media as the Greek case. However, statistics show that you should look at it a little more exactly.

Basic data on the international investment position do not show anything unusual. Net international investment position of Ireland is negative. In relation to gross domestic product it adopts one of the lowest values in the European Union. However, NIIP does not differ significantly from the other PIIGS countries. A signal to the in-depth study gives the value of NIIP per capita, which is the lowest in the European Union - about -33.4 thousand. EUR (in the case of Spain which is second from the end in this respect net IIP is equal -21.1 thousand EUR). However, the set of the indicators of financial dependence proposed in this paper shows the true scale of the problem. As mentioned above, the ratio of external liabilities to gross domestic product amounted in Ireland about $1700 \%$. It is very strange that in the case of other countries presented in this paper, this ratio reached the average level of about $200 \%$. It should be noted that the share of foreign direct investment (considered as a kind of stabilizer of international investment position) in the external liabilities amounted to less than $7 \%$ at the end of the analyzed period in the case of Ireland. Only Greek liabilities had a lower percentage of FDI (less than 6\%). For comparison, the share of FDI in the Spanish external liabilities amounted to over $20 \%$.

Portfolio investments constitute the most of external liabilities of Ireland. This type of investment is relatively unstable, and usually is characterized by a short planning horizon. It is also often a form of speculation. In the case of Ireland, the majority of foreign portfolio investments in total external liabilities are ordinary shares - more than 66\%. Debt instruments, especially bonds, constitute a quite a large part of the above-mentioned investments - more than 571.6 billion (more than $20 \%$ of total foreign liabilities). This amount is more than $350 \%$ of gross domestic product.

The total amount of external debt may raise even more interest. By the standards of the IMF it is calculated as total Irish liabilities in comparison to non-residents of excluding ordinary shares and derivatives. According to the Central Bank of Ireland the total external debt at the end of 2011 amounted to almost EUR 1.7 billion. This means that the external debt exceeded Irish gross domestic product more than ten times [9].

\section{Conclusions}

The analysis presented in this paper shows that the PIIGS countries are financially dependent on the external entities. This dependence is reflected in both by the debt of public sector, as well as private enterprises. 
In some cases, the size of financial dependence is so high that it is interesting that the situation hasn't yet got out of control. This is not an optimistic sign for the future. In this situation, the stability of whole European Union may be at risk.

Therefore it is necessary to take action to reduce excessive external debt not only by the public sector but also the private sector. The financial stability of private corporations is as important as the stability of the state budget. Large corporations (especially in the financial sector) falling into trouble, expect that they will receive the public aid. This has an impact on the deterioration of the financial stability of governments and the increasing level of debt.

One should also take a closer look at the international statistics. A comparison of official data on the ratio of the debt of Ireland to its gross domestic product (106\%) with the components of the international investment position one can assume that these statistics are underestimated. History has already shown (the case of Greece) that the long-term published false macroeconomic statistics is not impossible.

\section{References}

[1] Balance of Payments Manual, International Monetary Fund, http://www.imf.org/external/np/sta/bop/bop.htm $(10.10 .2013)$.

[2] Sohnke M. Bartram, Gunter Dufey, International Portfolio Investment: Theory, Evidence and Institutional Framework, Michigan 2001, p.3.

[3] Global Risk2011, Sixth Edition, An Initiative of the Risk Response Network, Word Economic Forum, Cologny-Geneva 2011, p. 3-50.

[4] The foreign investment should be understood as the sum of: foreign direct investment, foreign portfolio investment (stocks and bonds) and other investments (trade credits, loans and so-called other liabilities).
[5] These activities have been repeatedly undertaken against the Polish zloty and they were attributed to a well-known, global financial corporations, such as Goldman Sachs and JP Morgan; see for example: To speculation on zloty confessed Goldman Sachs, ISB, http://www.money.pl/gospodarka/wiadomosci/artykul/do;sp ekulacji;na;zlotym;przyznal;sie;goldman;sachs, 125,0,42892 5.html (30.09.2013).

[6] EUROSTAT, Government finance statistics, Summary tables - 1/2012, Statistical Books, European Union 2013.

[7] Bank of Greece, Statistics Department, International Investment Position, http://www.bankofgreece.gr/BogDocumentEn/International Investment_Position-Data.xls (25.04.2013); BANCO DE ESPAÑA, BALANZA DE PAGOS Y POSICIÓN DE INVERSIÓN INTERNACIONAL DE ESPAÑA, Madrid 2011, p. 137; Foreign assets and liabilities of Hungary, 1995 2012. (excluding SPE's), Magyar Nemzeti Bank, http://english.mnb.hu/Statisztika/data-and-information/mnbe n_statisztikai_idosorok/ mnben elv external trade/mnben fizm 20090330 (25.04.2013); BPA01: International Investment Position by Type of Investment, Year and Statistic, Central Statistics Office, Ireland, http://www.cso.ie/px/pxeirestat/statire/SelectVarVal/Define.a sp? Maintable $=$ bpa01\&PLanguage $=0 \quad$ (25.04.2013); International Investment Position Statistics, Estatisticas online, Banco de Portugal, http://www.bportugal.pt/PAS/SEM/src/(S(hciebhzbfwwc434 5wxtuwm45) $/$ Analise.aspx?book $=\{$ ED97D27C-4626-4EF3 -9215-CE4DD6073F2D $\} \&$ Page $=\{$ EC2638D0-4FD6-4B7C9CC2-572DECE14632\} (25.04.2013).

[8] Piotr Siemiatkowski, Grzegorz Gorniewicz, Introduction to International Capital Flows, Torun (Poland) 2006, p.86.

[9] Quarterly International Investment Position and External Debt, Central Statistics Office, http://www.cso.ie/en/media/csoie/releasespublications/docu ments/economy/2011/qiipexd_q42011.pdf (6.10.2013). 